\title{
A Panel Analysis of the Impact of Green Transformation and Globalization on the Labor Share in the National Income
}

\author{
Małgorzata Gawrycka ${ }^{1, *(D)}$ and Anna Szymczak ${ }^{2}$ \\ 1 Department of Finance, Faculty of Managent and Economics, Gdańsk University of Technology, \\ 80-233 Gdańsk, Poland \\ 2 Faculty of Economics and Social Sciences, Sopot University of Applied Science, 81-855 Sopot, Poland; \\ anna.szymczak@ssw-sopot.pl \\ * Correspondence: mgaw@zie.pg.gda.pl
}

Citation: Gawrycka, M.; Szymczak, A. A Panel Analysis of the Impact of Green Transformation and Globalization on the Labor Share in the National Income. Energies 2021, 14, 6967. https://doi.org/10.3390/ en14216967

Academic Editor:

Oleksandr Melnychenko

Received: 29 September 2021

Accepted: 17 October 2021

Published: 23 October 2021

Publisher's Note: MDPI stays neutral with regard to jurisdictional claims in published maps and institutional affiliations.

Copyright: (c) 2021 by the authors. Licensee MDPI, Basel, Switzerland. This article is an open access article distributed under the terms and conditions of the Creative Commons Attribution (CC BY) license (https:/ / creativecommons.org/licenses/by/ $4.0 /)$.

\begin{abstract}
This study aims to examine the impact of green transition and globalization processes on changes in the labour share. The study covers 76 national economies diversified in development, global production share and energy transition stage from 2000 to 2018. Based on the Total Economy Database data, panel models of the relationship between green transition, globalization and the labour share in the national income were estimated. The conducted Breusch-Pagan and Hausman tests proved the validity of using fixed-effects models. We confirmed the research hypothesis that the openness of the economy contributes to a decline in the labour share. The openness of the economy resulting from globalization reduces the labour share in the national income. We do not confirm hypotheses that suggest energy transition contributes to a reduction in the labour share and that the labour share will decline in the post-crisis period due to the lower bargaining power of workers. Changes in the labour share should be of interest to government representatives who influence the shape and implementation of economic policy, especially in employment policy, education, and investment policy, mainly aimed at the green transformation.
\end{abstract}

Keywords: labour share; globalization; green growth; panel data model

\section{Introduction}

Despite the dynamic growth of labour productivity observed since the 1990s, no increase in the labour share was recorded. The consequences of this phenomenon, unfavourable for income distribution in the economy, are being discussed in the context of economic policy, particularly for employment policy [1]. The literature mentions many factors determining the share of work in the national income. Researchers define their impact in various ways and often focus their attention on a selected aspect such as openness of the economy, technological changes, and structural changes [2-9]. However, it should be emphasized that energy transition processes and the popularity of the green growth concept also affect the labour sphere, and thus, the economy's labour and capital intensity [10-20].

The main drivers of labour participation change are outlined in the International Labor Office report [21], which provides answers as to why the labour share is decreasing? One of the factors exposed in the study is the processes of globalization. The research results of the above-mentioned report concern the beginnings of globalization (1990-2004). Since globalization and integration will intensify in the following decades, the authors considered it essential to study the influence of these processes on shaping the labour share in the national income. Due to the correlation between the phenomena, attention has been focused on globalization [21].

Globalization can be treated as a process resulting from expanding and deepening interdependencies between countries, regions, societies, and economic entities [22]. Globalization has accelerated due to technological progress in transport and communication, 
trade liberalization and deregulation, and the freedom of capital movements at the national and international levels [23]. Although researchers assess its impact ambiguously, globalization is associated with green growth $[19,24-28]$. However, there is no doubt that countries that are more open to foreign trade and technological innovations are moving faster towards a green growth policy [27]. Thus, we cannot separate the green economy and openness of countries, as they are intertwined by default.

Globalization as a process is characterized by many connections and interactions between economic entities operating in the modern world. This phenomenon is influenced by the following factors [28-31]:

- increase in exports of goods and services, liberalization of global financial markets, deregulation of antitrust law, company mergers;

- the presence of new entities on the global stage, e.g., international corporations, the emergence and growing importance of regional integration structures;

- new rules and standards of conduct, e.g., respecting human rights, intellectual property, increasing environmental awareness;

- new means of international communication;

- deregulation of the financial market;

- multilateral trade liberalization;

- regional economic integration.

The factors mentioned above can be classified according to four criteria, i.e., economic, institutional, political, and social criteria. The following study focuses only on the economic aspect. The ongoing changes in the labour share caused by globalization processes shape the capital-labour relations, both in the national economy and between individual countries [32]. This problem seems to be particularly important from the point of view of current national and international economic policy, based on sustainable development goals (SDG) [33]:

- Goal 1, "No poverty" - aims to eradicate poverty in all its forms in the world.

- Goal 7, "Affordable and clean energy" - aims to ensure stable, sustainable, and modern energy access.

- Goal 8, "Decent work and economic growth" — relates to promoting stable, sustainable and inclusive growth, full and productive employment.

- Goal 10, "Reduced inequalities" - aims to reduce inequalities within and between countries.

The ongoing energy changes resulting from the sustainable development goals are being analyzed on both global and European levels [34-37].

One effect of globalization is the openness of economies [38], which can be measured, among other things, in trade and capital flows. Therefore, the following variables were used to conduct the research: inflow and outflow of foreign direct investment [39], the share of exports and imports in GDP [40], and exchange rates [41]. While green growth and the energy transition have been presented through energy import, the use of primary energy [42], renewable energy consumption [43] and $\mathrm{CO}_{2}$ emission [44]. A diverse group of countries was selected for the research regarding development, geographic location, size and share in global production, and energy transition stage. The study divided economies into homogeneous groups using the FTSE Russell (FTSE Russell is a wholly owned subsidiary of London Stock Exchange Group (LSEG), and is a unit of the Information Services Division.) criterion concept formulated in the previous century [45-47]. These researchers drew attention to the cross-sectoral proportions, in terms of employment and production. From the research's point of view, Fourastie's [47] concept is vital, as the division criterion he used was the dynamics of technological progress. He distinguished three sectors of the national economy. Sector 1 includes activities characterized by low dynamics of technological advancement; Sector 2 includes branches with moderate dynamics of technological progress, and; Sector 3 includes branches where technological progress is high. Using the three-sector division made it possible to group national economies according to their 
similar level of development while eliminating the influence of technological differentiation on research results.

Globalization, the accompanying changes in the structure of the national economy, or changes in development, may impact the inhabitants' quality of life and standard of living [48]. Extensive use of resources in production processes, on the one hand, may contribute to changes in the structure of the national economy and the development of these economies, e.g., through the growth of highly specialized services or production processes [32]. On the other hand, it may threaten sustainable development processes [49] and accelerate climate change, the social aspects of which should be considered [17]. Additionally, the research was carried out separately for two periods, i.e., 2000-2009 and 2010-2018. The reason for this division was the willingness to confront the results obtained by Jayadev [50], which show that economic crises do not affect the labour share.

This study examines the impact of green transition and globalization processes on changes in the labour share. The following research hypotheses are related to the above goal:

Hypothesis H1. The more developed country, the lower the labour share favouring the capital share.

Hypothesis H2. The openness of the economy contributes to a decline in the labour share in national income.

Hypothesis H3. The energy transition contributes to a decline in the labour share in national income.

Hypothesis H4. The labour share in national income will decline in the post-crisis period due to the reduction of workers' wage pressures.

\section{Literature Review}

An essential role in shaping the relationship between work and capital in the economy is played by globalization processes, which Harrison [3] dealt with in her research, looking for models indicating the factors determining the labour share in the national income. In her opinion, e.g., financial openness enabling the flow of capital between individual countries (inflow of foreign direct investment) reduces the importance of work, which means that capital matters more than work in the national income. When there are restrictions on the flow of capital, the labour share increases. Currency fluctuations, which reduce the labour share in the national income, also proved to be an essential factor. Research conducted by Harrison [3] on a sample of over 100 countries shows that before 1993, the labour share in the national income decreased by an average of one percentage point in one decade. These statements were made for countries with a lower level of development. After the period above, the labour share in national income decreased faster, by about three percentage points within a decade. In countries characterized by a higher level of development, the share of work increased on average by two percentage points during the decade preceding 1993. Then, over the decade, the share of work in the analyzed countries decreased by four percentage points. These data indicate a reversal trend after 1993 for countries with a high level of development and an acceleration of the downward trend for countries with a low level of development. Moreover, it was noted that there are discrepancies between individual countries belonging to the same group. For example, Canada, Japan and Switzerland recorded an increase in labour productivity since 1970, while in most European countries, it decreased [3].

Research by Lee and Jayadev [4] conducted in 1973-1995 shows that the country's openness lowers the share of work, both in countries with a high level of development and in developing countries. This effect is independent of the impact of financial crises. During financial crises, and in the short term after, the share of labour declines and remains low even as national income "recovers" to pre-crisis levels. All empirical studies show that financial openness and financial crises reduce labour share in national income $[4,37]$. 
Onaran [1] research for the Austrian economy conducted in the period from 1990-2005 shows that the processes of globalization and integration, in particular with the countries of Eastern Europe, harmed both employment and wages. The adverse effects concern all sectors of the economy that require low and high professional qualifications. Since the Austrian economy belongs to the group of "relatively small countries", the processes accompanying globalization may have an above-average impact on the analyzed phenomena in the labour market. However, this aspect will not be the subject of in-depth research. Conversely, the research conducted by Stockhammer [21] for 71 OECD countries in the years from 1970-2007 shows that globalization and the accompanying phenomena contributed to the reduction of employees' wages, which translates into a lower share of work in the national income, which is confirmed by research conducted for the Austrian economy.

Cheng et al. [51], in their study on Chinese provinces from 2001-2015, show that technological progress was the crucial factor in enhancing green total factor productivity growth, and the type of growth itself is described as "capital-intensive and labour-saving, and energy-intensive and labour-saving". Nieto et al. [52] claim that the energy transition process causes structural change, steering the economy towards the labour-intensive and less energy-intensive sector. They also suspect that an increase in the labour share could contribute to decoupling human well-being from economic growth.

Given the above, it seemed interesting to investigate whether the studied phenomena accompanying globalization intensified and affected the processes of green transformation and changes in the labour share in the national income.

In the literature, a lot of space is devoted to research determining the impact of business power [53] and the impact of the workforce [17] on changes in sustainable development and green revolution. However, very little has been said about the implications of green transformation for shifts in the labour share in national income. We aim to fill this research gap.

\section{Materials and Methods}

Using panel data models, this study estimated the impact of green transition and globalization on labour share in national income. We wanted to investigate whether green transition and globalization have the same effect on labour share in different economies. Thus, the subject of the analysis is 76 countries included in FTSE Equity Country Classification [54] in the period from 2000-2018. Due to missing data, Hong Kong, Taiwan, Syria and Palestine were omitted from the analysis. We decided to use such a research sample and the resulting countries classification because the FTSE Global Equity Index Series (GEIS) dates back to the late 1980s and is one of the most transparent and evidence-driven indices. The categorization of countries within the index is not arbitrary and is not based only on the wealth of nations but it also considers the materiality, stability, consistency, predictability and quality of the market [55]. The data used in the investigation were obtained from the Total Economy Database [56], World Bank, UNCTADstat and IMF-World Economic Outlook. Table 1 presents the data used in our models. Detailed results of the analysis will be shown in the next section.

The variables included in the model were selected based on the literature review. The inclusion of variables related to green growth in the model is an innovative approach and, to the authors best knowledge, has not yet been empirically verified. In their study, Doan and Wan [56] show that the inward and outward FDI flows have a statistically significant influence on labour share in developed countries (although their direction of impact is different, outward FDI influences positively, while inward negatively). In developed countries, they [56] also showed that TFP and the industry share harmed the labour share in national income. In their study [57], export and import were treated as separate factors, not as openness indicator in Guscina's research [9]. Guerriero [57] found a negative and significant relationship between the GDP and labour share in national income. Harrison [3] found that changes in labour shares are driven by government spending, exchange rate 
crises and movements in foreign investment. Finally, the interrelationship between inflation and labour share is discussed in Lawless and Whelan [58].

Table 1. Variables used in the investigation.

\begin{tabular}{ccc}
\hline Variable Name & Description & Source \\
\hline LS & the logarithm of share of total labour compensation in GDP & TED \\
FDI_I & the logarithm of foreign direct investment: inward flow as \% of GDP & UNCTADstat \\
FDI_O & the logarithm of foreign direct investment: outward flow as \% of GDP & UNCTADstat \\
REER & the logarithm of the real effective exchange rate index & UNCTADstat \\
Open & the logarithm of average imports and exports in relation to GDP & UNCTADstat \\
ICT & the logarithm of the share of ICT capital compensation in GDP & TED \\
GDPg & growth of GDP, change in the natural log & TED \\
TFPg & growth of total factor productivity & TED \\
GDPp & the logarithm of GDP per capita-US dollars at constant prices (2015) & UNCTADstat \\
CPI & consumer price indices, annual & UNCTADstat \\
GC & the logarithm of general government final consumption expenditure as \% of GDP & UNCTADstat \\
Man & the logarithm of GDP share of manufacturing & UNCTADstat \\
EU & the logarithm of the energy use (kg of oil equivalent per capita) & World Bank \\
REC & the logarithm of renewable energy consumption (\% of total final energy consumption) & World Bank \\
$\mathrm{CO}{ }_{2}$ & the logarithm of CO ${ }_{2}$ emissions (metric tons per capita) & World Bank \\
\hline
\end{tabular}

Source: Authors' elaboration.

We applied panel data regressions to verify the hypothesized impact of the variables connected with globalization on the labour share (LS). The starting point for the estimation was the following pool model $[59,60]$ :

$$
y_{i t}=\alpha+\sum_{i=1}^{n} \beta_{j} x_{j i t}+u_{i t}
$$

where $y_{i t}$-dependent variable in the $i$-th country in year $t, x_{i j t}-j$-th independent variable in $i$-th country in year $t, \alpha$-intercept, $\beta_{j}$-structural parameters, $u_{i t}$-error term.

Later, we applied panel diagnostics tests—Breusch-Pagan and Hausman tests [61] - to choose between random and fixed effects models as the limitations of pooled ordinary least squares OLS are known [62].

In a fixed-effects model (FE), the intercept controls individual-specific and timeinvariant characteristics [63]:

$$
y_{i t}=\alpha_{i}+\sum_{i=1}^{n} \beta_{j} x_{j i t}+u_{i t}
$$

where $\alpha_{\mathrm{i}}$-individual intercept in the i-th country.

The random effects (RE) model, on the other hand, makes it possible to estimate the effects of variables that are individually time-invariant:

$$
y_{i t}=\alpha+\sum_{i=1}^{n} \beta_{j} x_{j i t}+u_{i t}
$$

where:

$$
\mathrm{u}_{\mathrm{it}}=\mu_{\mathrm{i}}+\varepsilon_{\mathrm{it}}
$$

$\mathrm{u}_{\mathrm{it}}$ - error component, $\mu_{\mathrm{i}}$ individual-specific random component, $\varepsilon_{\mathrm{it}}$ idiosyncratic disturbance.

The internal validity of the models has been investigated. The validation concerned the equations' form of the model (linear, non-linear, lags of diagnostic variables and the dependent variable, as well as spatial autocorrelation). Groups of countries were considered constant and have not been changed from the original split from FTSE. Various estimation methods were also considered (1)-(3). The models presented in the next section 
are models that meet the conditions of formal correctness for econometric models. The research carried out by $[3,17,56-58]$ showed that it is justified to divide countries into more homogeneous groups in the case of the labour share models. Models for all entities tend to be of poorer quality, and parameter assessments are too generalized (cancelling out negative and positive effects).

\section{Results}

Panel data models were estimated separately for each of the four groups of countries (Figure 1) identified by the FTSE in the periods from 2000-2009 and from 2010-2018. The first period covers the pre-crisis years and the financial crisis itself, while the second is the post-crisis period. We also wanted to check whether the direction of influence of individual determinants has changed due to the financial crisis.

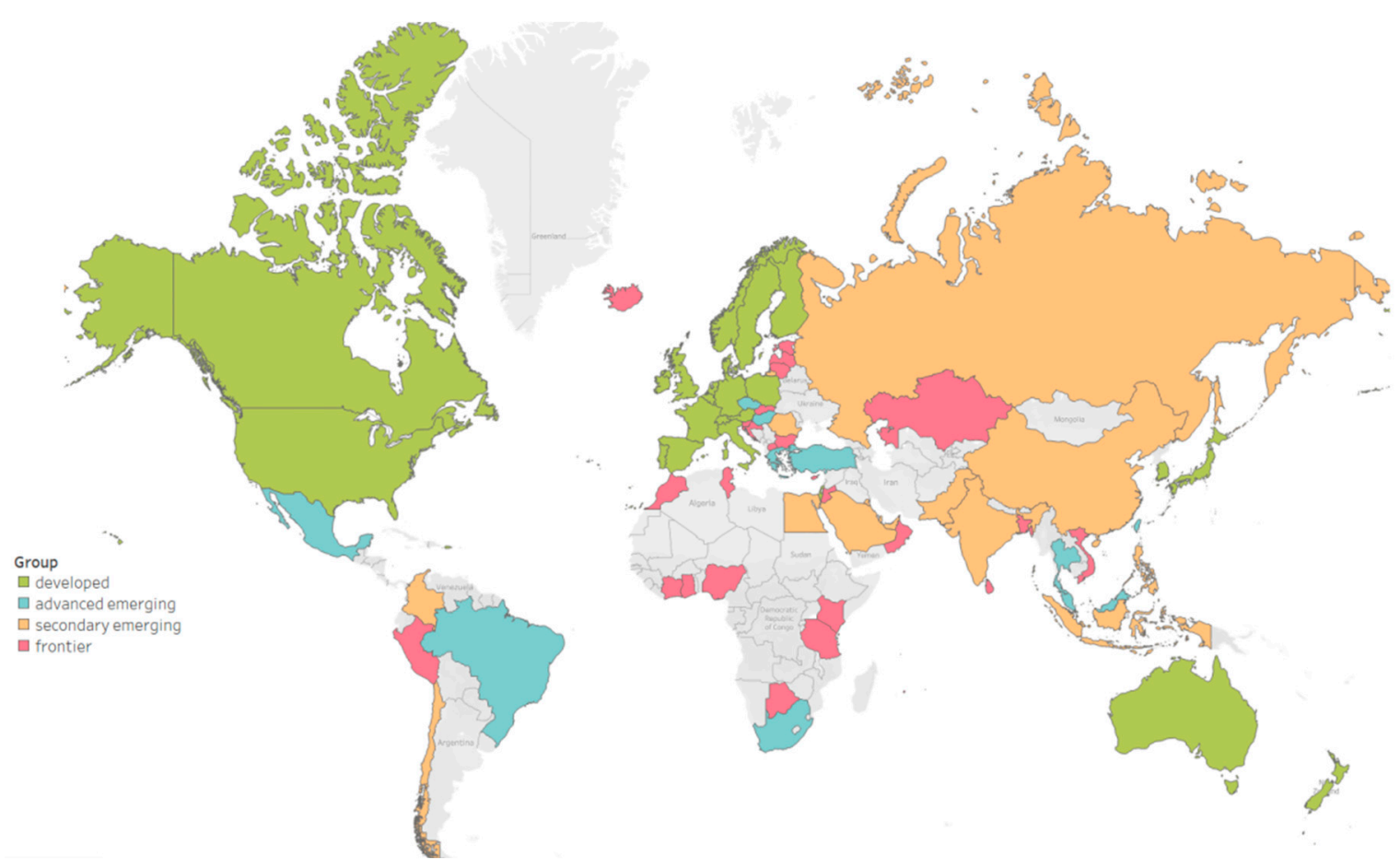

Figure 1. Group of countries under investigation according to FTSE. Source: FTSE Equity Country Classification [54].

Table 2 presents the employment structure and labour share in 2018 in analyzed groups of countries.

Table 2. The average employment structure in 2018 in the analyzed group of countries.

\begin{tabular}{ccccc}
\hline & \multicolumn{3}{c}{ Group of Countries } \\
\hline & Developed (DV) & Advanced Emerging (AE) & Secondary Emerging (SE) & Frontier (FR) \\
\hline $\begin{array}{c}\text { Employment in } \\
\text { services (in \%) }\end{array}$ & 75.6 & 62.0 & 54.7 & 57.8 \\
\hline $\begin{array}{c}\text { Employment in } \\
\text { industry (in \%) }\end{array}$ & 19.8 & 25.8 & 27.1 & 23.2 \\
\hline $\begin{array}{c}\text { Employment in } \\
\text { agriculture (in \%) }\end{array}$ & 4.6 & 12.2 & 18.2 & 19.0 \\
\hline Labour share (in \%) & 54.0 & 53.4 & 43.7 & 46.2 \\
\hline
\end{tabular}

Analyzing the data in Table 2, it can be noticed that in the Developed group (DV) consisting of 25 countries (e.g., Australia, Canada, Germany, Japan), employment in services 
dominates, with a marginal percentage of people working in agriculture. However, the highest labour share is recorded in this group, which most likely results from the significant share of employment in KIBS (Knowledge-Intensive Business Services). The Advanced Emerging (AE) group consisting of nine countries (e.g., Brazil, Mexico, Turkey, Greece) is characterized by lower, but still predominant, employment in the service sector, with more than $12 \%$ of jobs in agriculture. The labour share in these economies is on average $53.4 \%$ and is close to the share in the DV group. More than ten percentage points lower labour share in national income was observed in the Secondary emerging (SE) group, with the lowest percentage of employment in services (54.7\%) and the highest percentage of employment in industry (27.1\%). This group includes economies such as China, India, Russia and Pakistan. In the last, the Frontier (FE) group, which consists of 28 countries (e.g., Bangladesh, Nigeria, Oman, Cyprus), the labour share is below 50\%. These countries recorded the highest average employment rate in agriculture and significant employment in industry.

When analyzing the data contained in Table 3, one can also notice apparent differences between the discussed groups of countries. DV countries are characterized by almost three times higher GDP per capita level than other nations; they are also countries with the highest ICT capital compensation in GDP and the highest government final consumption expenditure as a percentage of GDP. These are described by high energy consumption, high $\mathrm{CO}_{2}$ emissions and a relatively high share of renewable energy sources. On the other hand, AE countries are distinguished by the lowest energy consumption and the lowest FDI flow. The SE countries are those with the highest GDP growth and, simultaneously, the most significant the decline in TFP. The countries from the Frontier group have the most remarkable economic openness and the highest share of renewable energy sources, which translates into the lowest average $\mathrm{CO}_{2}$ emissions.

Table 3. The average value of explanatory variables in 2018 in the analyzed group of countries.

\begin{tabular}{ccccc}
\hline \multicolumn{5}{c}{ Group of Countries } \\
\hline Explanatory Variables & Developed (DV) & Advanced Emerging (AE) & Secondary Emerging (SE) & Frontier (FR) \\
\hline FDI_I & 4.61 & 1.61 & 2.45 & 13.67 \\
FDI_O & 4.89 & 1.35 & 2.22 & 7.57 \\
REER & 100.97 & 109.95 & 137.87 & 121.44 \\
Open & 55.71 & 47.62 & 34.59 & 56.22 \\
ICT & 3.33 & 3.15 & 2.90 & 2.92 \\
GDPg & 1.46 & 2.35 & 4.66 & 3.70 \\
TFPg & -0.29 & -0.22 & -0.74 & -0.10 \\
GDPpc & 47670.75 & 11821.80 & 15175.54 & 11672.61 \\
CPI & 1.08 & 0.59 & 13.99 & 3.85 \\
GC & 19.97 & 17.31 & 3894.00 & 15.15 \\
EU & 4399.45 & 2488.81 & 15.58 & 2960.24 \\
REC & 19.97 & 17.12 & 9.11 & 30.42 \\
CO2 & 8.30 & 5.56 & & 4.67 \\
\hline
\end{tabular}

At the beginning of the study, the correlation between all variables was calculated based on the data from 2018. We took into consideration the labour share and also variables relating to globalization and green growth (Figure 2).

If we analyze all countries together, it turns out that the LS shows only a weak negative correlation with the openness of the economy and $\mathrm{CO}_{2}$ emissions. Thus, it is impossible to verify the first hypothesis at the current stage, and it is justified to break down the further analysis into more homogeneous groups. Slightly more apparent results were obtained considering the correlation relationships between the variables related to green transformation (REC, EU, $\mathrm{CO}_{2}$ ), which are negatively correlated with economic growth and productivity growth (EU and $\left.\mathrm{CO}_{2}\right)$, exposed in the seventh Sustainable Development Goal. As for the REC, it is positively correlated with the above, which is a positive phenomenon. So, the 
more developed economies, the faster the processes of green transformation (increasing the share of REC, a decrease of EU and $\mathrm{CO}_{2}$ ). However, due to the relatively low values of Pearson's linear correlation coefficients, it seems reasonable to refine further analyses into four separate groups (Figure 2).

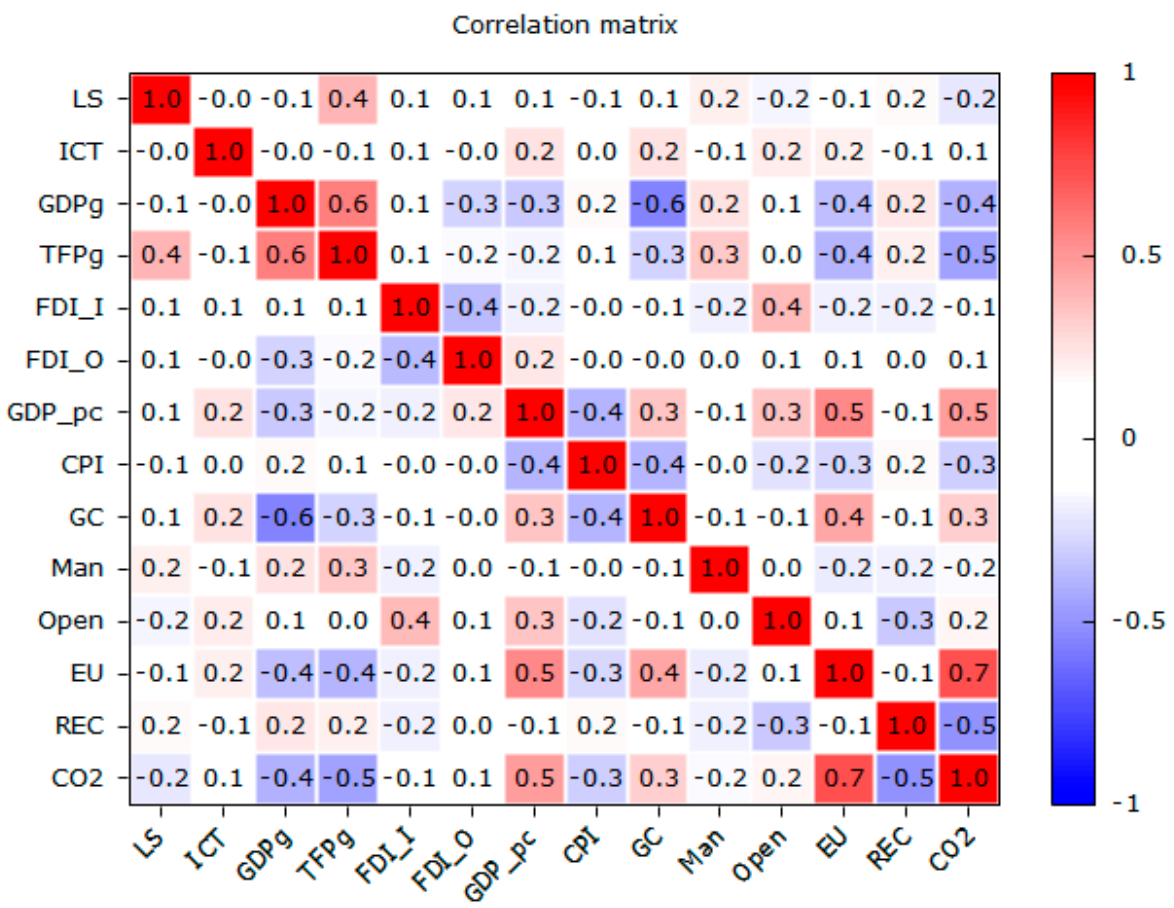

Figure 2. Correlation matrix among variables used in the investigation (data for 2018).

The results of the intended analysis (estimates of panel data models) are presented in Table 4.

Table 4. Labour share estimates *.

\begin{tabular}{ccccccccc}
\hline \multirow{2}{*}{ Variable } & \multicolumn{3}{c}{ Period 2000-2009 } & & & \multicolumn{2}{c}{ Period 2010-2018 } \\
\cline { 2 - 9 } & DV & AE & SE & FR & DV & AE & SE & FR \\
\hline \multirow{2}{*}{ FDI_I } & 0.0013 & -0.010 & -0.022 & 0.013 & 0.001 & -0.002 & 0.020 & -0.002 \\
& $(0.573)$ & $(0.061)$ & $(0.015)$ & $(0.025)$ & $(0.733)$ & $(0.503)$ & $(0.202)$ & $(0.743)$ \\
\hline \multirow{2}{*}{ FDI_O } & 0.0013 & -0.002 & $0.0070 .241)$ & 0.003 & -0.001 & 0.005 & 0.004 & 0.003 \\
& $(0.582)$ & $(0.620)$ & & $(0.388)$ & $(0.704)$ & $(0.102)$ & $(0.671)$ & $(0.476)$ \\
\hline \multirow{2}{*}{ REER } & 0.017 & -0.199 & -0.135 & 0.142 & -0.010 & -0.068 & -0.022 & -0.135 \\
& $(0.521)$ & $(0.0001)$ & $(0.075)$ & $(0.004)$ & $(0.630)$ & $(0.048)$ & $(0.769)$ & $(0.014)$ \\
\hline \multirow{2}{*}{ Open } & -0.085 & -0.182 & 0.029 & -0.113 & -0.063 & -0.070 & -0.157 & -0.040 \\
& $(0.030)$ & $(0.0001)$ & $(0.618)$ & $(0.009)$ & $(0.032)$ & $(0.019)$ & $(0.085)$ & $(0.207)$ \\
\hline \multirow{2}{*}{ ICT } & 0.015 & -0.059 & -0.042 & 0.002 & -0.001 & -0.036 & -0.142 & -0.012 \\
& $(0.390)$ & $(0.114)$ & $(0.225)$ & $(0.870)$ & $(0.954)$ & $(0.087)$ & $(0.023)$ & $(0.372)$ \\
\hline \multirow{2}{*}{ GDPg } & 0.001 & 0.001 & -0.010 & -0.001 & -0.005 & -0.002 & 0.004 \\
& $(0.851)$ & $(0.845)$ & $(0.019)$ & $(0.515)$ & $(0.006)$ & $(0.069)$ & $(0.497)$ & $(<0.0001)$ \\
\hline \multirow{2}{*}{ TFPg } & -0.002 & -0.003 & 0.004 & 0.000 & 0.003 & -0.001 & -0.005 & 0.014 \\
& $(0.207)$ & $(0.325)$ & $(0.253)$ & $(0.981)$ & $(0.075)$ & $(0.418)$ & $(0.452)$ & $(0.0001)$ \\
\hline \multirow{2}{*}{ GDPpc } & -0.146 & 0.000 & 0.002 & -0.001 & -0.183 & 0.000 & 0.072 & -0.050 \\
& $(0.0001)$ & $(0.775)$ & $(0.974)$ & $(0.979)$ & $(<0.0001)$ & $(0.348)$ & $(0.594)$ & $(0.399)$ \\
\hline
\end{tabular}


Table 4. Cont

\begin{tabular}{|c|c|c|c|c|c|c|c|c|}
\hline \multirow{2}{*}{ Variable } & \multicolumn{4}{|c|}{ Period 2000-2009 } & \multicolumn{4}{|c|}{ Period 2010-2018 } \\
\hline & DV & $\mathrm{AE}$ & SE & FR & DV & $\mathrm{AE}$ & SE & FR \\
\hline$C P I$ & $\begin{array}{c}0.002 \\
(0.062)\end{array}$ & $\begin{array}{c}0.001 \\
(0.017)\end{array}$ & $-0.0(0.117)$ & $\begin{array}{c}0.002 \\
(0.144)\end{array}$ & $\begin{array}{l}-0.001 \\
(0.582)\end{array}$ & $\begin{array}{c}0.001 \\
(0.046)\end{array}$ & $\begin{array}{c}0.002 \\
(0.392)\end{array}$ & $\begin{array}{l}-0.006 \\
(0.002)\end{array}$ \\
\hline GC & $\begin{array}{c}0.248 \\
(<0.0001)\end{array}$ & $\begin{array}{l}-0.100 \\
(0.257)\end{array}$ & $\begin{array}{c}0.194 \\
(0.018)\end{array}$ & $\begin{array}{c}-0.078 \\
(0.0001)\end{array}$ & $\begin{array}{c}0.247 \\
(<0.0001)\end{array}$ & $\begin{array}{c}0.123 \\
(0.098)\end{array}$ & $\begin{array}{c}0.382 \\
(0.001)\end{array}$ & $\begin{array}{c}0.090 \\
(0.048)\end{array}$ \\
\hline Man & $\begin{array}{c}0.057 \\
(0.023)\end{array}$ & $\begin{array}{l}-0.041 \\
(0.668)\end{array}$ & $\begin{array}{c}0.047 \\
(0.556)\end{array}$ & $\begin{array}{c}0.148 \\
(0.018)\end{array}$ & $\begin{array}{l}-0.058 \\
(0.030)\end{array}$ & $\begin{array}{c}0.037 \\
(0.383)\end{array}$ & $\begin{array}{c}0.065 \\
(0.588)\end{array}$ & $\begin{array}{l}-0.023 \\
(0.624)\end{array}$ \\
\hline$E U$ & $\begin{array}{l}-0.044 \\
(0.270)\end{array}$ & $\begin{array}{l}-0.011 \\
(0.943)\end{array}$ & $0.195(329)$ & $\begin{array}{l}-0.047 \\
(0.569) \\
\end{array}$ & $\begin{array}{c}0.031 \\
(0.550) \\
\end{array}$ & $\begin{array}{l}-0.053 \\
(0.342)\end{array}$ & $\begin{array}{l}-0.277 \\
(0.040)\end{array}$ & $\begin{array}{c}0.170 \\
(0.014)\end{array}$ \\
\hline REC & $\begin{array}{l}-0.015 \\
(0.063)\end{array}$ & $\begin{array}{c}0.019 \\
(0.684)\end{array}$ & $\begin{array}{c}-0.076 \\
(0.393)\end{array}$ & $\begin{array}{c}0.021 \\
(0.555)\end{array}$ & $\begin{array}{l}-0.009 \\
(0.305)\end{array}$ & $\begin{array}{c}0.044 \\
(0.019)\end{array}$ & $\begin{array}{l}-0.022 \\
(0.343)\end{array}$ & $\begin{array}{c}0.048 \\
(0.083)\end{array}$ \\
\hline $\mathrm{CO} 2$ & $\begin{array}{l}-0.056 \\
(0.188)\end{array}$ & $\begin{array}{c}0.084 \\
(0.611)\end{array}$ & $\begin{array}{l}-0.316 \\
(0.112)\end{array}$ & $\begin{array}{l}-0.054 \\
(0.347) \\
\end{array}$ & $\begin{array}{l}-0.013 \\
(0.630)\end{array}$ & $\begin{array}{c}0.054 \\
(0.223)\end{array}$ & $\begin{array}{l}-0.210 \\
(0.130)\end{array}$ & $\begin{array}{c}0.043 \\
(0.410)\end{array}$ \\
\hline Units & 25 & 9 & 14 & 28 & 25 & 9 & 14 & 28 \\
\hline Within-R2 & 0.490 & 0.518 & 0.583 & 0.232 & 0.675 & 0.748 & 0.410 & 0.512 \\
\hline LSDV-R2 & 0.980 & 0.981 & 0.977 & 0.951 & 0.987 & 0.993 & 0.976 & 0.944 \\
\hline BP Test & $(<0.0001)$ & $(<0.0001)$ & $(<0.0001)$ & $(<0.0001)$ & $(<0.0001)$ & $(<0.0001)$ & $(<0.0001)$ & $(<0.0001)$ \\
\hline H Test & 0.002 & ** & $* *$ & 0.0005 & 0.001 & $* *$ & $* *$ & 0.001 \\
\hline
\end{tabular}

* $p$-value is given in parentheses; constant calculated but not reported. The symbols for the models' variables are described in Table 1 in the previous section. DV—-developed, AD—advanced emerging, SE—secondary emerging, FR—frontier. ${ }^{* *}$ not enough observations. Source: Authors' elaboration.

Analyzing the data in Table 4 makes it possible to confirm the different impacts of individual determinants depending on the group of surveyed countries. There are also differences in the effects of individual variables depending on the investigated subperiod. Therefore, breaking them into subgroups was a justified solution.

Thus, in the case of developed countries (DV-the group consisted of 25 items); it turned out that in the pre-crisis period, labour share was negatively affected by renewable energy consumption and the degree of economic openness. Interestingly, most variables strictly related to globalization (FDI inward and outward, REER) and green transformation (EU, REC, $\mathrm{CO}_{2}$ ) were statistically insignificant in the post-crisis period. In the case of control variables, GDP per capita, GDP growth and total factor productivity (in 2010-2018) harmed labour share, while government consumption (GC, in both periods), GDP share of manufacturing (in 2000-2009) and CPI (in 2000-2009) turned out to be positive for labour share. Interestingly, during the post-crisis period, the direction of GDP impact generated by industry changed (Man). Now, it negatively impacts LS, which may signify a shift to more capital-intensive technologies. Developed national economies before the crisis used their total production capacity to "drain the labour market". Enterprises operate in the so-called "employee market", which is manifested by pressure from trade unions and employees to increase wages. By optimizing their activities, enterprises are often forced to make investment decisions that increase labour productivity (labour substitution with capital) or transfer work processes to other countries with lower costs, facilitating globalization. The described situation applies, in particular, to highly developed countries characterized by high labour productivity. It should be emphasized that the activities of enterprises are focused on increasing their value, regardless of the conditions in which they operate. This is justified by the research results, which indicate that GDP per capita rise harms the labour share. In the case of the DV group countries, neither the emission intensity of the economy nor energy consumption contributed to changes in the labour share in the national economy. This may prove that the changes in DV countries affect industry to a greater extent than the service sector, which employs the majority of employees. 
Advanced emerging (AE) countries turned out to be particularly sensitive to most variables related to globalization in both periods but in a slightly different shape. In the pre-crisis period, all variables except FDI_O negatively influenced the changes in the share of labour. However, in the post-crisis period, FDI_I also lost its statistical importance. The direction of REER and Open impact remained unchanged. The outflow of foreign investment did not affect the share of labour in the national economy, while the other three variables contributed to its reduction. Until that time, a statistically significant (negative) effect was noted for the level of economies' openness and REER. These countries primarily base their development on the inflow of technology and capital from highly developed countries. The inhibition of this process during the crisis changes the direction of the influence of the analyzed factor. In the case of this 9-element group of countries, most of the control variables turned out to be statistically insignificant in the pre-crisis period. Consumer Price Index contributed to the increase in labour share, as in developed countries in both periods. Inflationary pressure influences the growth of employees' wages in a time shift relative to the rise in the prices of goods and services, which may increase the share of labour in the national income. A positive impact in the post-crisis period was observed for government consumption, while the decrease in the labour share was influenced by ICT capital compensation and GDP growth. In most cases, the green energy variables did not play a statistically significant role in the AE countries. Only the REC in the period from 2010-2018 turned out to be statistically significant and, most likely, results from the aforementioned green technology flow from higher developed countries.

Secondary emerging (SE) countries turned out to be the least sensitive to the variables included in the study. In this case, two variables (FDI_I and REER) were statistically significant in the pre-crisis period, while after that time, only Open turned out to harm LS. In the pre-crisis period, similarly to $\mathrm{AE}$, the exchange rate and FDI inward contributed to its labour share reduction. At the same time, the value of GDP per capita caused its reduction. In the period from 2010-2018, the decrease of LS was caused by economic openness and deepened by the negative impact of ICT and energy usage. However, in both analyzed sub-periods, government expenditure increased the labour share. Neither the $\mathrm{CO}_{2}$ emission intensity nor the development of renewable energy sources contributed to a change in the economy's capital and labour intensity.

The largest group-Frontier ( 28 countries), in the post-crisis period, turned out to be the most sensitive to the variables related to green and sustainable growth. Both the energy consumption (EU) and the percentage of renewable energy contributed (REC) positively to the volume of LS, indicating the shift towards energy-saving and labour-intensive economy. In the pre-crisis period, the inflow of foreign investments and exchange rates contributed to the growth of labour share. This is because globalization facilitates the flow of capital between countries and enables flexible adaptation of resources used in the activities of enterprises to the changing economic account, which is influenced in particular by labour costs. As a result of optimization, work processes are transferred to countries with an even lower level of development. Also, in FR group, the economy' openness contributes to a decline in the labour share (but only in the period from 2000-2009). Various directions of GC impact, depending on the analyzed period, were also noted. However, this is not a very surprising phenomenon because it could be explained by the fact that government spending is generally not based on an economic calculation. Their impact on the share of work in the national income may vary depending on the implemented economic policy, particularly the social policy of a given country. As for the post-crisis period, labour share was much more influenced by the diagnostic variables selected for the model. From control variables, only TFP growth and GC influenced the increase in the labour share, while the remaining ones contributed to its decrease (GDPg, CPI). This is most likely caused by the fact that during a crisis, the state may use tools to stimulate economic activity through intervention and regulatory actions, which results in an expansionary economic policy. At the same time, enterprises strive to use free production capacity to increase their productivity. 


\section{Discussion and Conclusions}

Previous studies, e.g., conducted by Prinz and Pegels [17] have devoted much attention to determining the impact of business power on changes in sustainable development [53]. Slightly less attention was put on the effect of the workforce [17]. However, very little attention has been paid to the consequences for labour share changes, which was the subject of interest for the authors of the study. According to the author's best knowledge, no research has been conducted on the impact of green growth on labour share in the national income. This work was intended to fill this research gap.

The research results confirm that the introduced division of countries according to their level of development is fully justified. Previous studies $[3,9,17,56-58]$ also demonstrated the validity of the division into more homogeneous groups. The level of development and openness shape the relationship between the green transformation, globalization process and the share of work in the national income. The impact of openness on the labour share has already been observed by [3,4,57]. In six out of eight models, it turned out that the impact of the "Open" variable was negative and statistically significant, which is not entirely consistent with the research results achieved by [4,57], as their research shows that the level of development of the country does not affect the observed relations.

However, it should be borne in mind that the openness of the economy cannot be reduced to just one variable expressing the relationship between exports and imports [56]. It is a broad concept that also takes into account exchange rates and the inflow of foreign direct investment $[9,56]$. Taking these other factors into account, it turns out that their degree of impact varies depending on group affiliation. Consequently, the most vital relationship between openness and labour share was observed in the advanced emerging group. This is because these countries often base their development on the inflow of technologies and capital from highly developed countries. The labour share in the secondary emerging countries turned out to be the least sensitive to the impact of globalization factors. It can be explained by the expansive economic policy and the fact that enterprises strive to use free production capacity to increase their productivity, confirming the first and second hypotheses.

Our analyses confirmed the hypothesis about the impact of globalization on the labour share in national income; however, this impact is not the same in all countries, nor is it constant depending on the analyzed period. Therefore, it may be due to the ability of individual economies to deal with crises, and also their initial level of industrialization. The unchanging (negative) direction of the impact was observed only in the case of exchange rates and the openness of the economy, which is in line with the research carried out by $[50,58,63]$.

Interestingly, the share of manufacturing in GDP turned out to be statistically significant and negative only in the post-crisis period in developed (DV) countries, while it was positive before the crises in DV and FR. Moreover, GDP per capita negatively influenced the size of labour share, but only in the post-crisis period (except SE countries). Therefore, it can be concluded that the fourth hypothesis has not been confirmed.

In terms of green development, the hypothesis that energy transition contributes to a decline in the labour share in national income was not confirmed

The discussed topic is crucial from the point of view of creating pro-social economic policy eliminating drastic income differences, which [21] pointed out in his research is vital for sustainable development. Changes in the labour share should be of interest to government representatives influencing the shape and implementation of this policy by selecting appropriate assumptions for education, investment and employment policies. The conducted research shows that the present observations should be continued, considering the current conditions related to the functioning of economies, which may significantly affect the capital-labour relationship. These are aspects associated with the industrial revolution (Industry 4.0), energy transition, the resulting change in the production process, and structural changes in economies resulting from the pandemic. 
The study's main limitation is the analysis period, which ends in 2018 and does not consider the latest changes in the labour market resulting from the digital revolution. It should be emphasized that the research did not consider an important aspect related to the industrial revolution (Industry 4.0) and the resulting changes in the production process, including through automation and robotization, influencing the shaping of the capital-labour relationship. Due to the research period, the current aspect related to the pandemic - changing the functioning of enterprises in an open economy (e.g., disruption of supply chains) was omitted.

In the future, the research should be expanded to include the impact of the energy transformation on social inequalities in connection with the labour share both on a European and on a global scale. This would allow for examining the achievement of goals 1 and 10 of sustainable development. Energy transformation is a global and a European priority [38]. At the same time, on the scale of individual countries, there is a different degree of its implementation, resulting in diverse social and economic costs translating into the level of economic development (8th Sustainable Development Goal) [32].

It should also be noted that the energy transformation generates cross-sector flows on a national and global scale, which may contribute to social inequalities and changes in the labour share, and thereby reflect structural changes in economies [47].

Author Contributions: Conceptualization, M.G. and A.S.; methodology, M.G.; software, M.G.; formal analysis, M.G.; investigation, M.G. and A.S.; resources, A.S.; writing-original draft preparation, M.G. and A.S.; writing-review and editing, M.G. and A.S.; visualization M.G.; supervision, M.G. All authors have read and agreed to the published version of the manuscript.

Funding: This research received no external funding.

Conflicts of Interest: The authors declare no conflict of interest.

\section{References}

1. Onaran, O. The Effects of Globalization on Wages, Employment, and Wage Share in Austria. 2018, Vienna. Available online: https: //www.arbeiterkammer.at/infopool/akportal/The_Effects_of_Globalization_on_Emplayment.pdf (accessed on 3 April 2020).

2. Bentolila, S.; Saint-Paul, G. Explaining Movements in the Labor Share. B.E. J. Macroecon. 2003, 1-33. [CrossRef]

3. Harrison, A.E. Has Globalization Eroded Labor's Share? Some Cross-Country Evidence. In MPRA Working Paper; Technical Report 39649; 2005; Available online: https:/ / mpra.ub.uni-muenchen.de/39649/1/MPRA_paper_39649.pdf (accessed on 6 September 2021).

4. Lee, K.; Jayadev, A. The Effects of Capital Account Liberalisation on Growth and the Labor Share of Macroeconomics. Available online: https: / peri.umass.edu/fileadmin/pdf/ns/NSarjun.pdf (accessed on 6 June 2020).

5. Gollin, D. Getting Income Shares Right. J. Political Econ. 2002, 110, 458-474. [CrossRef]

6. Fields, G. Self-employment and Poverty in Developing Countries. J. Political Econ. 2014, 110. [CrossRef]

7. de Serres, A.; Scarpetta, S.; de la Maisonneuve, C.H. Sectoral Shifts in Europe and the United States. In OECD Economics Department Working Papers, 2002; No. 326; OECD Publishing: Paris, France, 2002. Available online: http://gesd.free.fr/shifts2.pdf (accessed on 6 September 2021).

8. Arpaia, A.; Perez, E.; Pichelmann, K. Understanding Labour Income Share Dynamics in Europe. In European Economy; Economic Papers; European Commission: Brussels, Belgium, 2009; Volume 379.

9. Guscina, A. Effects of Globalization on Labor's Share in National Income; IMF Working Paper, 06/294; IMF: Washington, DC, USA, 2006.

10. Pietrzak, M.B.; Igliński, B.; Kujawski, W.; Iwański, P. Energy Transition in Poland-Assessment of the Renewable Energy Sector. Energies 2021, 14, 2046. [CrossRef]

11. OECD. Employment Implications of Green Growth: Linking Jobs, Growth, and Green Policies; OECD Report for the G7; Environment Ministers, 2017. Available online: https:/ / www.oecd.org/environment/Employment-Implications-of-Green-Growth-OECDReport-G7-Environment-Ministers.pdf (accessed on 14 January 2018).

12. Lucan, G. The Impacts of the Energy Transition on Growth and Income Distribution [in:] M. Hafner and S. Tagliapietra (eds.), The Geopolitics of the Global Energy Transition. Lect. Notes Energy 2020, 73, 305-318.

13. WEF. Fostering Effective Energy Transition. 2021. Available online: https://www3.weforum.org/docs/WEF_Fostering_Effective_ Energy_Transition_2021.pdf (accessed on 13 May 2021).

14. Fagnart, J.F.; Germain, M. Quantitative versus qualitative growth with recyclable resource. Ecol. Econ. 2011, 70, 929-941. [CrossRef] 
15. Dupont, E.; Germain, M.; Jeanmart, H. Feasibility and Economic Impacts of the Energy Transition. Sustainability $2021,13,5345$. [CrossRef]

16. Füllemann, Y.; Moreau, V.; Vielle, M.; Vuille, F. Hire fast, fire slow: The employment benefits of energy transitions. Econ. Syst. Res. 2019, 32, 202-220. [CrossRef]

17. Prinz, L.; Pegels, A. The role of labour power in sustainability transitions: Insights from comparative political economy on Germany's electricity transition. Energy Res. Soc. Sci. 2018, 41, 210-219. [CrossRef]

18. Wang, P.; Zhang, Z.; Zeng, Y.; Yang, S.; Tang, X. The Effect of Technology Innovation on Corporate Sustainability in Chinese Renewable Energy Companies. Front. Energy Res. 2021. [CrossRef]

19. Hoffmann, U. Can Green Growth Really Work and what are the True (Socio-) Economics of Climate Change. In United Nations Conference on Trade and Development. Discussion Paper; 2015; p. 222. Available online: https:/ / unctad.org/webflyer/can-greengrowth-really-work-and-what-are-true-socio-economics-climate-change-ulrich (accessed on 13 May 2021).

20. Jacob, K.; Quitzow, R.; Bar, H. Green Jobs: Impacts of a Green Economy on Employment; Deutsche Gesellschaft für Internationale Zusammenarbeit (GIZ) GmbH: 2015. Available online: https:/ / www.greengrowthknowledge.org/sites/default/files/ downloads/resource/Jacob,\%20Quitzow,\%20B\%c3\%a4r\%202014\%20Green\%20Jobs_ENGLISH.pdf (accessed on 23 April 2021).

21. Stockhammer, E. Why Have Wage Shares Fallen? A Panel Analysis of the Determinants of Functional Income Distribution; Conditions of Work and Employment Series; ILO: Geneva, Switzerland, 2013; p. 35.

22. Oziewicz, E. (Ed.) Przemiany We Wspótczesnej Gospodarce Światowej; PWE: Warszawa, Poland, 2006.

23. Globalization and Liberalisation Effects of International Economic Relations on The Least Developed Countries; UNCTAD/ECDC/PA/4/Rev; Geneva, Switzerland, 1996; Volume 1. Available online: https:/ / unctad.org/system/files/official-document/ldc1996_en.pdf (accessed on 9 June 2020).

24. Anser, M.K.; Usman, M.; Godil, D.I. Does globalization affect the green economy and environment? The relationship between energy consumption, carbon dioxide emissions, and economic growth. Environ. Sci. Pollut. Res. 2021, 28, 1-4. [CrossRef]

25. Asongu, S.A.; Nnanna, J. Globalization, Governance, and the Green Economy in Sub-Saharan Africa: Policy Thresholds. World Aff. 2021, 184, 176-212. [CrossRef]

26. Tang, S.; Wang, Z.; Yang, G.; Tang, W. What Are the Implications of Globalization on Sustainability?-A Comprehensive Study. Sustainability 2020, 12, 3411. [CrossRef]

27. Zafar, M.; Kousar, S.; Sabir, S.A. Impact of Globalization on Green Growth: A Case of OECD Countries. J. Indian Stud. 2019, $5,231-244$.

28. Herman, K.S. Green growth and innovation in the Global South: A systematic literature review. Innov. Dev. 2021, 1-27. [CrossRef]

29. Zaorska, A. Ku globalizacji? Przemiany w Korporacjach Transnarowodych i w Gospodarce Światowej; PWE: Warsaw, Poland, 2002.

30. Stiglitz, J.E. Globalizacja; PWN: Warsaw, Poland, 2004.

31. Piasecki, R. Rozwój Gospodarczy a Globalizacja; PWN: Warsaw, Poland, 2003.

32. Tiba, S.; Omri, A. Literature Survey on the Relationships between Energy, Environment and Economic Growth. Renew. Sustain. Energy Rev. 2017, 69, 1129-1146. [CrossRef]

33. United Nations. Transforming Our World: The 2030 Agenda for Sustainable Development, Resolution Adopted by the General Assembly on 25 September 2015; 2015. Available online: https://www.un.org/en/development/desa/population/migration/ generalassembly/docs/globalcompact/A_RES_70_1_E.pdf (accessed on 23 April 2021).

34. Sompolska-Rzechuła, A.; Kurdyś-Kujawska, A. Towards Understanding Interactions between Sustainable Development Goals: The Role of Climate-Well-Being Linkages. Experiences of EU Countries. Energies 2021, 14, 2025. [CrossRef]

35. Hernandez, R.R.; Jordaan, S.M.; Kaldunski, B.; Kumar, N. Aligning Climate Change and Sustainable Development Goals with an Innovation Systems Roadmap for Renewable Power. Front. Sustain. 2020, 1, 583090. [CrossRef]

36. Gatto, A.; Drago, C. A taxonomy of energy resilience. Energy Policy 2020, 136, 111007. [CrossRef]

37. Gajdzik, B.; Grabowska, S.; Saniuk, S.; Wieczorek, T. Sustainable Development and Industry 4.0: A Bibliometric Analysis Identifying Key Scientific Problems of the Sustainable Industry 4.0. Energies 2020, 13, 4254. [CrossRef]

38. Melnychenko, O. Ukrainian Market of Electrical Energy: Reforming, Financing, Innovative Investment, Efficiency Analysis, and Audit. Energies 2021, 14, 5080. [CrossRef]

39. Gräbner, C.; Heimberger, P.; Kapeller, J.; Springholz, F. Understanding economic openness: A review of existing measures. Rev. World Econ. 2021, 157, 87-120. [CrossRef]

40. Cibulskiene, D.; Maciulyte-Sniukiene, A. Evaluation of the impact of economic openness on labour productivity in EU countries Cent. East. Eur. J. Manag. Econ. 2014, 2, 225-253.

41. Habib, M.M.; Mileva, E.; Stracca, L. The real exchange rate and economic growth: Revisiting the case using external instruments. J. Int. Money Financ. 2017, 73, 386-398. [CrossRef]

42. Tawiah, V.; Zakari, A.; Adedoyin, F.F. Determinants of green growth in developedand developing countries. Environ. Sci. Pollut. Res. 2021, 28, 39227-39242. [CrossRef] [PubMed]

43. Hallegatte, S.; Heal, G.; Fay, M.; Treguer, D. From Growth to Green Growth-A Framework; NBER Workin Paper Series; $2011 ;$ p. 17841. Available online: https:/ / www.nber.org/system/files/working_papers/w17841/w17841.pdf (accessed on 20 August 2021).

44. Bowen, A.; Hepburn, C. Green growth: An assessment. Oxf. Rev. Econ. Policy 2014, 30, 407-422. [CrossRef]

45. Fisher, A.G. The Economic Implications of Material Progress. Int. Labour Rev. 1939, 32, 5.

46. Clark, C. The Conditions of Economic Progres; MacMilian: London, UK, 1951. 
47. Fourastie, J. Myśli Przewodnie; Państwowy Instytut Wydawniczy: Warsaw, Poland, 1996.

48. Kuc-Czarnecka, M.E.; Olczyk, M.; Zinecker, M. Improvements and Spatial Dependencies in Energy Transition Measures, Measures. Energies 2021, 14, 3802. [CrossRef]

49. Healy, N.; Barry, J. Politicizing energy justice and energy system transitions: Fossil fuel divestment and a "just transition". Energy Policy 2017, 108, 451-459. [CrossRef]

50. Jayadev, A. Capital account openness and the labour share of income. Camb. J. Econ. 2007, 31, 423-443. [CrossRef]

51. Cheng, Z.; Li, L.; Liu, J. Research on China's industrial green biased technological progress and its energy conservation and emission reduction effects. Energy Effic. 2021, 14, 1-20. [CrossRef]

52. Nieto, J.; Carpintero, Ó.; Lobejón, L.F.; Miguel, L.J. An ecological macroeconomics model: The energy transition in the EU. Energy Policy 2020, 145, 111726. [CrossRef]

53. FTSE Russel. FTSE Equity Country Classification March 2021 Interim Update. 2021. Available online: https:/ / research.ftserussell. $\mathrm{com} /$ products/downloads/FTSE-Country-Classification-Update_latest.pdf (accessed on 27 April 2021).

54. FTSE Russel. FTSE Equity Country Classification Process, September 2021. Available online: https://research.ftserussell.com/ products / downloads /FTSE_Equity_Country_Classification_Paper.pdf?_ga=2.140757938.1827811411.1631013797-646606433.16 17273360 (accessed on 23 April 2021).

55. TED (2020). The Conference Board Total Economy Database ${ }^{\mathrm{TM}}$ (Original Version), July 2020. Available online: https://www. conference-board.org (accessed on 7 April 2021).

56. Doan, H.T.T.; Wan, G. Globalization and the Labor Share in National Income; ADBI Working Papers; Asian Development Bank Institute: Tokyo, Japan, 2017; p. 639. Available online: https:/ /www.adb.org/sites/default/files/publication/223671/adbi-wp639.pdf (accessed on 12 April 2021).

57. Guerriero, M. Democracy and Labour Share of Income: A Cross-Country Analysis; ADBI Working Paper Series; Asian Development Bank Institute: Tokyo, Japan, 2019.

58. Lawless, M.; Whelan, K. Understanding the Dynamics of Labour Shares and Inflation; European Central Bank Working Paper Series; European Central Bank: Frankfurt am Main, Germany, 2007; p. 784.

59. Biørn, E. Econometrics of Panel Data: Methods and Applications; Oxford University Press: Oxford, UK, 2016; Published to Oxford Scholarship Online: December 2016. [CrossRef]

60. Stock, J.H.; Wathon, M.W. Introduction to Econometrics 4th Global Edition; Pearson Education Limited: Harlow, UK, 2020.

61. Arrelano, M.; Bond, S. Some tests of specification for panel data: Monte Carlo evidence and an application to employment equations. Rev. Econ. Stud. 1991, 58, 277-297. [CrossRef]

62. Torres-Reyna, O. Panel Data Analysis Fixed and Random Analysis Using Stata; Data and Statistical Services: Princeton University; Princeton University: New York, NJ, USA, 2007.

63. Ibarra, C.A.; Ros, J. The decline of the labour share in Mexico 1990-2015. In Capital Flight and Capital Controls in Developing Countries; Esptein, G., Ed.; WIDER Working Paper; 2017/183; Income Distribution, Conditions of Work and Employment Series No. 35 (Geneva: ILO). Income: Reviewing and Extending the Cross-Country Evidence; Cheltenham Edward Elgar, 2017. Available online: https:/ / www.wider.unu.edu/sites/default/files/Publications/Working-paper/PDF/wp2017-183.pdf (accessed on 7 April 2021). 